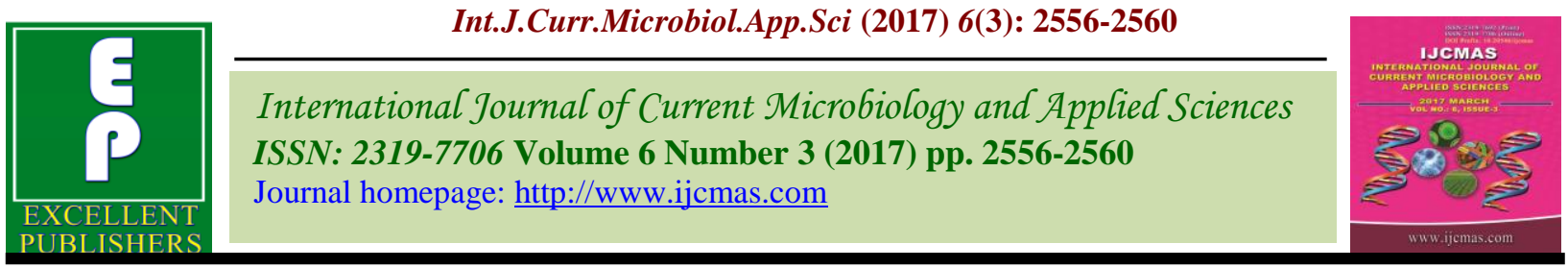

Original Research Article

https://doi.org/10.20546/ijcmas.2017.603.289

\title{
Response of Lentil to Thiourea Application under Rain Fed Conditions of Central India
}

\author{
R.P. Singh ${ }^{1} *$ and Dasharath Singh $^{2}$ \\ ${ }^{1}$ Division of Agronomy, R.A.K. Collage of Agriculture (RVSKVV), \\ Sehore - 466109 (M.P.), India \\ ${ }^{2}$ Department of Agricultural Economics \& Farm Management (JNKVV), \\ Jabalpur - 482004 (M.P.), India \\ *Corresponding author
}

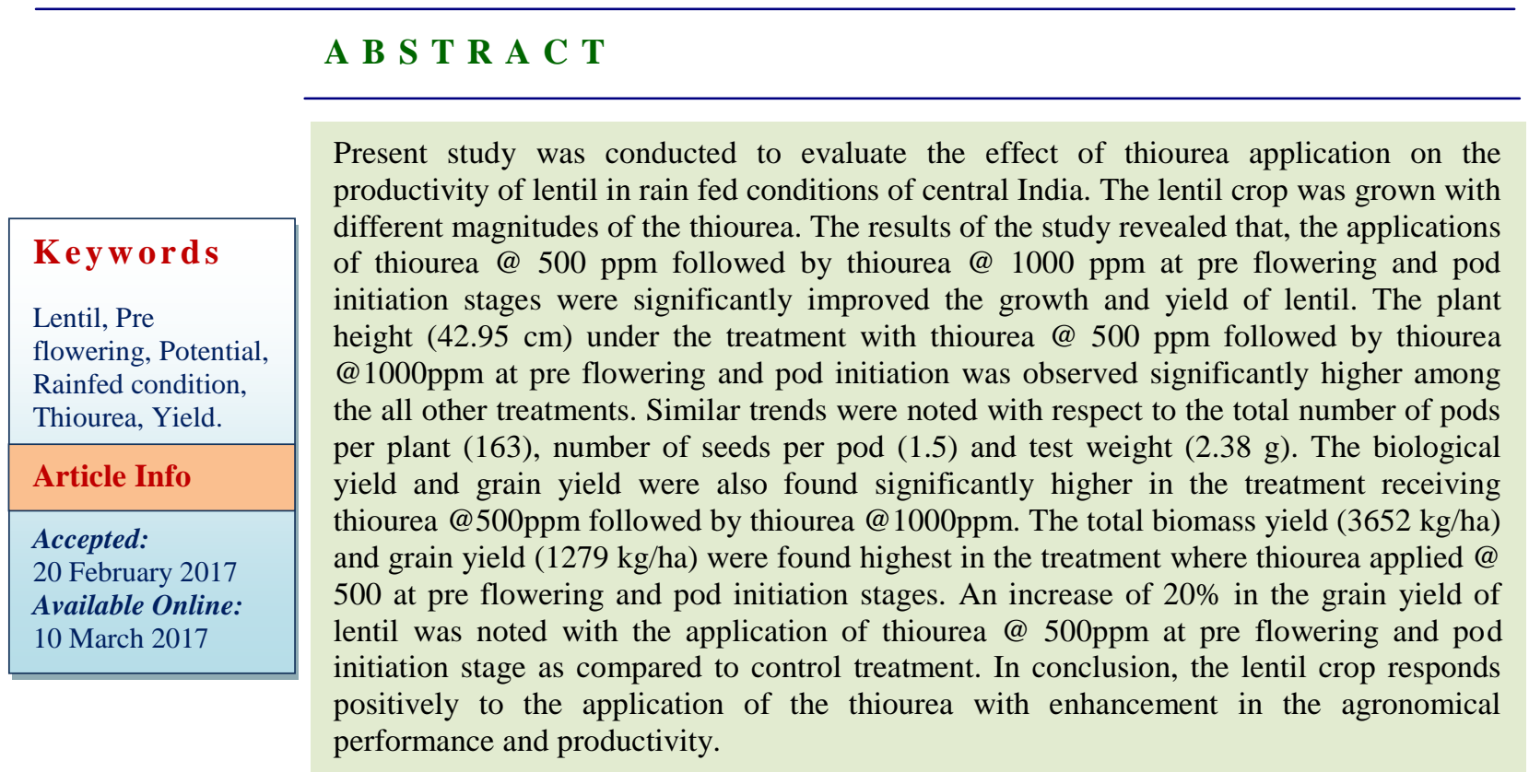

\section{Introduction}

Lentil is the most widely cultivated pulse crop grown under rainfed conditions in Madhya Pradesh. The less availability of the water affects the growth and productivity of the crop. The plant growth regulators viz. thiourea known to tolerate the deficiency of moisture (Asthir et al., 2013). Plant growth regulators like sulphahydryl is well known to enhance the source sink relationship and stimulate the translocation of photo-assimilates thereby helping in effective flower initiation, fruit and seed development and ultimately enhance productivity of the crops. Growth regulator can improve the physiological efficiency of crop including photosynthetic ability and can enhance the effective partitioning of accumulates from source and sink in the field crops (Solamani et al., 2001). Thiourea is the most important of which include exogenous application of stress alleviating agents. 
Thiourea is a sulphahydral compound and help to improve productivity and its role as a drought tolerant is well established under the arid and semi-arid regions (Sahu et al., 1993).Thiourea have $42 \%$ sulphur and $36 \%$ of nitrogen. Thus, it behaves in physiology of plants both as a sulphahydryl compound and as an amino compound like urea (Garg et al., 2006). The stimulatory action of thiourea in various physiological processes of plant. It is mainly used for its dormancy breaking and germination stimulating effect. Several researchers working on many crops had reported that the use of growth substances is one of the effective means of delaying the senescence of leaves. The beneficial eff ects of thiourea were attributed to its role in significantly increasing the net photosynthetic rates and the concentrations of total chlorophyll and starch in the leaves (Burman et al., 2004). The present study was conducted to evaluate the response of lentil crop to the application of the thiourea in rainfed conditions in central India.

\section{Materials and Methods}

The present investigation was conducted at the RAK College of agriculture, Sehore (RVSKVV) for three consecutive years, 2012- 2014. Lentil cv. JL-30 was grown under rain fed conditions. The experimental soil was a clayey with $7.1 \%$ clay, $5.6 \%$ silt, $63.1 \%$ fine sand and $24.0 \%$ coarse sand contains $0.28 \%$ organic carbon and $0.023 \%$ total nitrogen. The soil have $80 \mathrm{~kg}$ available $\mathrm{N}, 12 \mathrm{~kg}$ available $\mathrm{P}$ and $120 \mathrm{~kg}$ available $\mathrm{K}$. The moisture con tent of the experimental soil was $10.0 \%$ at field capacity $(\mathrm{w} / \mathrm{w})$ and $3.0 \%$ at permanent wilting point (15 bars), respectively. Lentil was sown in field plots on second fortnight of November. Thirteen treatments were laid out in randomized block design with four replications each. The treatment involving plant growth regulators viz. T1 - Control (no spray), T2 - Water spray at pre flowering, T3- Water spray at pod initiation, T4- Water spray at pre flowering + pod initiation,T5- Urea $2 \%$ spray at pre flowering, T6- Urea $2 \%$ spray pod initiation, T7- Urea $2 \%$ spray at pre flowering + pod initiation, T8- Thiourea 500 PPM at pre flowering, T9- Thiourea 500 PPM at pod initiation, T10 Thiourea 500 PPM at pre flowering + pod initiation, T11- Thiourea 1000 PPM at pre flowering, T12- Thiourea 1000 PPM at pod initiation, T13- Thiourea 1000 PPM at pre flowering + pod initiation. For analyzing the growth patterns of the crop viz., plant height and number of branches were recorded on five randomly selected plants in a plot of each treatment at different stages viz., 30 DAS, 60 DAS and maturity. The observations on yield parameters like number of pods per plant, number of seeds per pod, seed yield per plant and seed yield per hectare were recorded as per the standard procedures.

\section{Results and Discussion}

\section{Growth attributes}

The number of branches per plant is an important morphological character, directly related to yield in lentil. The foliar application of thiourea @ 500ppm at pre flowering and pod initiation stages significantly affect plant height. The maximum plant height $(42.95 \mathrm{~cm})$ and branches per plant (5.20) were recorded with application of thiourea @ 500ppm followed by of thiourea @ 1000ppm at pre flowering and pod initiation stages over water spray and control (Table 1). The maximum plant height and branches were attained under the treatment because thiourea increased the net photosynthetic rates and the concentrations of total chlorophyll and starch in the leaves. Thiourea has also been reported to significantly improve growth, yield and water use efficiency of mungbean, Yadav (2005). Thiourea induced increase in seed 
yield due to better translocation of photosynthates has also been reported earlier
Sahu and Solanki (1991), Parihar et al. (1998), Sharma et al. (2015).

Table.1 Effect of water and thiourea spray on growth and yield of lentil

\begin{tabular}{|c|r|r|r|r|r|r|r|r|}
\hline $\begin{array}{c}\text { Treatmen } \\
\text { ts }\end{array}$ & \multicolumn{1}{c|}{$\begin{array}{c}\text { Plant } \\
\text { height }\end{array}$} & \multicolumn{1}{c|}{$\begin{array}{c}\text { Branche } \\
\mathrm{s}\end{array}$} & Pods/plant & $\begin{array}{c}\text { Test } \\
\text { weight }\end{array}$ & $\begin{array}{c}\text { Seeds } \\
\text { /pod }\end{array}$ & $\begin{array}{c}\text { Biomass } \\
\text { yield } \\
\mathrm{kg} / \mathrm{ha}\end{array}$ & $\begin{array}{r}\text { Grain } \\
\text { yield } \\
\mathrm{kg} / \mathrm{ha}\end{array}$ & $\begin{array}{c}\text { Harvest } \\
\text { index } \%\end{array}$ \\
\hline $\mathrm{T}_{1}$ & 35.58 & 3.77 & 65.77 & 1.88 & 1.70 & 2374 & 795 & 33.54 \\
\hline $\mathrm{T}_{2}$ & 37.54 & 3.47 & 83.73 & 1.90 & 1.73 & 2243 & 758 & 33.71 \\
\hline $\mathrm{T}_{3}$ & 36.06 & 3.83 & 74.83 & 1.87 & 1.77 & 2585 & 869 & 33.78 \\
\hline $\mathrm{T}_{4}$ & 36.74 & 3.93 & 91.40 & 1.94 & 1.90 & 2861 & 972 & 34.01 \\
\hline $\mathrm{T}_{5}$ & 38.51 & 4.73 & 96.83 & 2.06 & 1.97 & 3220 & 1089 & 33.78 \\
\hline $\mathrm{T}_{6}$ & 38.39 & 3.93 & 91.67 & 2.10 & 2.10 & 3158 & 1070 & 33.90 \\
\hline $\mathrm{T}_{7}$ & 37.55 & 4.50 & 102.17 & 2.24 & 1.63 & 3519 & 1173 & 33.53 \\
\hline $\mathrm{T}_{8}$ & 38.63 & 4.17 & 120.23 & 1.98 & 1.90 & 3274 & 1121 & 34.06 \\
\hline $\mathrm{T}_{9}$ & 41.78 & 4.70 & 113.40 & 2.17 & 2.10 & 3325 & 1114 & 33.54 \\
\hline $\mathrm{T}_{10}$ & 42.95 & 5.20 & 163.17 & 2.38 & 1.50 & 3652 & 1279 & 34.92 \\
\hline $\mathrm{T}_{11}$ & 42.00 & 4.47 & 121.20 & 1.91 & 1.80 & 3269 & 1098 & 33.54 \\
\hline $\mathrm{T}_{12}$ & 40.45 & 4.37 & 105.77 & 2.10 & 1.70 & 3147 & 1062 & 33.63 \\
\hline $\mathrm{T}_{13}$ & 40.05 & 4.03 & 113.27 & 2.05 & 1.60 & 3228 & 1083 & 33.78 \\
\hline $\mathrm{SEm}_{\mathrm{SEd}}$ & 1.71 & 0.25 & 13.99 & 0.14 & 0.11 & 240 & 78 & 0.75 \\
\hline $\mathrm{CD}_{5} \%$ & $\mathbf{4 . 9 7}$ & $\mathbf{0 . 7 2}$ & $\mathbf{4 0 . 6 8}$ & $\mathbf{0 . 4 0}$ & $\mathbf{0 . 3 2}$ & $\mathbf{6 9 7}$ & $\mathbf{2 2 8}$ & $\mathbf{2 . 1 9}$ \\
\hline
\end{tabular}

Yield attributes and yield

Yield attributing parameters like pods per plant, seeds per pod and test weight are directly related to plant yield. The maximum pods per plant (163.17), seeds per pod (1.50) and test weight $2.38 \mathrm{~g}$ were recorded in treatment applying thiourea @ 500ppm at pre flowering and pod initiation stages over water spray and control treatment. The effect of thiourea on growth characters might be attributed due to stress mitigation effect and promote crop growth. These results were conformity with Anjum et al. (2008) and Bhunia et al. (2015).

Total biomass production $3652 \mathrm{~kg} / \mathrm{ha}$ and grain yield $1279 \mathrm{~kg} / \mathrm{ha}$ were recorded with the application of thiourea @ 500 ppm at pre flowering and pod initiation followed by the 
thiourea@1000 ppm at pre flowering. The improved yield through thiourea might be due to the increased photosynthesis and efficient transport of photosynthates towards the sink which ultimately leads to greater seed yield. The increase in the yield recorded in this investigation could be a reflection of the effect of thiourea on growth and development. The yield was higher due to increased in the number of branches per plant pods and hence more seeds, increase in the photosynthetic, which could lead to increase in photosynthesis, resulting in greater transfer of assimilates to the seeds and causing increase in their weight. These results are conformity with Mehta et al. (2002), Anitha et al. (2004), Anitha et al. (2006), Meena and sharma (2010).The harvest index of lentil was not affected by the application of thiourea at any stage. Harvest index was increased due to spraying the plants with the application of thiourea@ 500 ppm pre flowering and pod initiation as compared to control.

In conclusion the results of experiment indicated that the spray of thiourea @ 500pm at pre flowering and pod initiation stages followed by the application of thiourea @ $1000 \mathrm{ppm}$ at pre flowering and pod initiation significantly improved the growth and the yield of lentil. The positive effects of thiourea seems to be mediated through enhanced photosynthetic efficiency besides more efficient carbohydrate and nitrogen metabolism and translocation of photophynthets to different part of the plant.

\section{References}

Anitha, S., Purushothaman, S.M. and Sreenivasan, E. 2006. Response of Horse gram to thiourea application under rainfed condition. Legume Ressearch, 29 (2): 146-149.

Anitha, S., Sreenivasan, E. and Purushothaman, S.M.2004. Effect of thiourea application on cowpea [Vigna unguiculata (L.) Walp.] productivity under rain fed conditions. Journal of Tropical Agriculture, 42 (1-2): 53-54.

Anjum, F., A. Wahid, F. Javed and Arshad, M.2008. Influence of foliar applied thiourea on flag leaf gas exchange and yield parameters of bread wheat (Triticuma estivum) cultivars under salinity and heat stresses. International Journal of agriculture and Biology, 10: 619-26.

Asthir, B. Thapar, R., Farooq, M. and Bains, N.S. 2013. Exogenous application of thiourea improves the performance of late sown wheat by inducing terminal heat resistance. International Journal of Agriculture and Biology, 15: 13371342.

Bhunia, S. R., Verma, I.M., Sahu, M. P., Sharma, N. C. and Balai, K.2015. Effect of drip irrigation and bioregulators on yield, economics and water use of fenugreek (Trigonella foenum-graecum). Journal of Spices and Aromatic Crops, 24 (2): 102-105.

Burman, U., Garg, B.K. and Kathju, S.2004. Interactive effects of thiourea and phosphorus on clusterbean under water stress. Biologia Plantarum, 48 (1): 6165.

Garg, B. K., Burman, U. and Kathju, S. 2006. Influence of thiourea on photosynthesis, nitrogen metabolism and yield of clusterbean (Cyamopsis tetragonoloba (L.) Taub.) under rain fed conditions of Indian arid zone. Plant Growth Regulation, 48:237-245.

Meena, B.S. and Sharma, D.O. 2010. Relative efficiency of sources of $\mathrm{p}$ and bio regulators on pigeon pea (Cajanus cajan). Progressive Agriculture, 10 (2): 265-269.

Mehta, Y.K. and Sharma, D.O. 2002. Effect of bio regulators on growth and yield of pea cultivars. In: Plant Physiology for 
Sustainable Forestry, Agri-Horticulture and Industry. 23-28. Pointer Publisher, Jaipur.

Parihar, G.N., Sahu, M.P., Joshi, N.L. 1998. Nitrogen, sulphur and thiourea nutrition of pearl millet [Pennisetum glaucum (L) R. Br.] II. Effect on yield and yield components. Annals of arid Zone, 37: 59-67.

Sahu, M.P., Solanki, N.S.1991. Role of sulphydryl compounds in improving dry matter partitioning and grain production of maize (Zea mays L.). Journal of Agronomy and Crop Science, 167: 356-359.

Sahu, M.P., Solanki, N.S. and Dashora, L.N. 1993. Effect of Thiourea, thiamine and ascorbic acid on growth and yield of maize (Zea mays L.). Journal of Agronomy and Crop Science, 171: 65-
69.

Sharma, K. M., Asarey, R. and Verma, H. 2015. Response of wheat (Triticum Aestivum L.) to the foliar applied brassinosteroid and thiourea with recommended fertilization practice on farmer's fields. Plant Archives, 15 (2):729-732.

Solamani, A., Sivakumar, C., Anbumani, S.: Suresh, T. and Arumugam, K. 2001. Role of plant geowth regulators on rice production: A review. Agriculture Review, 23:33-40.

Yadav, L. R. 2005. Effect of bioregulators on productivity of wheat (Triticum aestivum L.) varieties under normal and late sown conditions. PhD Thesis, Rajasthan Agricultural University, Bikaner.

\section{How to cite this article:}

Singh, R.P. and Dasharath Singh. 2017. Response of Lentil to Thiourea Application under Rain Fed Conditions of Central India. Int.J.Curr.Microbiol.App.Sci. 6(3): 2556-2560. doi: https://doi.org/10.20546/ijcmas.2017.603.289 